INTERDISCIPLINARIA ARCHAEOLOGICA

Thematic review

\title{
Microscopic Analysis of Starch Grains and its Applications in the Archaeology of the Stone Age
}

\author{
Jaromír Kovárník $\mathrm{k}^{\mathrm{a}^{*}}$, Jaromír Beneš ${ }^{\mathrm{a}}$ \\ ${ }^{a}$ Laboratory of Archaeobotany and Palaeoecology, Faculty of Science, University of South Bohemia, Na Zlaté stoce 3, 37005 České Budějovice, Czech Republic
}

\section{ARTICLE INFO}

\section{Article history}

Received: 22 ${ }^{\text {nd }}$ August 2017

Accepted: $11^{\text {th }}$ September 2018

DOI: http://dx.doi.org/ 10.24916/iansa.2018.1.6

\section{Keywords:}

archaeobotany

starch morphology

amylase

amylopectine

soil

dental calculus

grinding stones

plant subsistence

Stone Age

\begin{abstract}
$A B S T R A C T$
Archaeobotanical micro-residuals are today a major focus in artefactual and bioarchaeological investigations. Though starch grains analysis may be regarded as marginal, it can be a useful analysis for archaeological research, being a method suitable for the investigation of stone artefacts and ceramic vessels. Soil samples and dental calculus can also be examined. Through the use of various extraction methods it is possible to answer questions of diet composition and purpose of stone tool use. As documented in recent studies examining the composition of the human diet, starch grain research should be one of the main areas of archaeobotanical investigation. Its applicability can be seen in studies where it is useful to define the role of plants in human subsistence. New evidence of plant use in archaeological contexts in the Stone Age, beginning in the Palaeolithic and ending in the Neolithic, has been presented in recent papers. Current archaeological studies, including those using starch grain analyses, have particularly indicated the higher ratio of plants in the diet during the Palaeolithic period.
\end{abstract}

\section{Introduction}

Archaeobotany offers a series of analytical methods (e.g. Evans, O'Connor, 1999). These various methods can be sorted according to the function and character of material studied, which may include seeds, stones of fruit, wood, charcoal and other botanical macro-remains on the one hand, and a large group of botanical microremains on the other (Jacomet, Kreuz, 1999). Integrated archaeobotanical approaches, which combine analyses of several biological indicators, began in the 1970s (Scott and Lewis, 1981; Cummings, 1994) and have become widespread due to their effectiveness as a tool for understanding the past environment, human diet, and the function of particular archaeological objects (Petö et al., 2013; García-Granero et al., 2015). The analysis of starch grains is a suitable, though still rather uncommon, archaeobotanical technique in archaeological research. However, starch grain analysis has been employed in archaeological research for more than

*Corresponding author. E-mail: jkovarnik@jcu.cz the last two decades. Starch grains are part of the group of plant microremains that includes phytoliths, pollen, spores and other "non-pollen" objects. Examination of these plant remains can elucidate changes in the environment, both natural and anthropogenic (Lentfer et al., 2002; Evans, Ritchie, 2005; Roosevelt, 2016). Starch occurs as insoluble, semi-crystalline granules in plant tissue that store energy in specific parts of the plant, such as seeds, roots and tubers (storage organs) (Hardy et al., 2016), and as transitory starch, which is usually not recovered or identified in samples. The analysis of starch grains is connected with investigations into plant use and plant processing in the past and also the composition of the herbaceous component of the human diet (Barton, White, 1993; Hall et al., 1989; Fullager et al., 1998; Henry et al., 2014; Corteletti et al., 2015; Tromp, Dudgeon, 2015; Shillito et al., 2018; López, 2018; Primavera et al., 2018). This technique is also suitable for research into the use and function of artefacts and for deciding issues of plant domestication and vegetation history (Loy et al., 1992; Hardy et al., 2009; Denham et al., 2003; Fuller et al., 2014; López, 2018, Cagnato, 2018; Albert et al., 2018). 
However, damaged starch grains can hinder the use of this particular technique. The results from starch grain analysis are suitable as complementary analyses to other techniques, such as palynology, phytolith analysis or plant macroremains (García-Granero et al., 2015; Pestle, Laffoon, 2018).

The examination of starch grains has improved along with improvements in microscopic technique. Antonia van Leeuwenhoek (1632-1723) was the first scientist to publish an illustration of starch grains. This Dutch scientist and microscopist engaged in the observation of natural materials and created a record of the starch grains of common species of plants such as wheat, barley, rye, oats, beans, peas, rice and corn (Hogg, 1854; Britannica, 2016). The work of
Fritzche continued that of Leeuwenhoek. He also recognized the potential of the heterogeneity of starch grains and its use for determining the genus and species of plants. It was only a short step towards the creation of taxonomic keys and atlases (Torrence, Barton, 2006). The German botanist and cofounder of cell theory, Matthias Jakob Schleiden (1804-1881), created a key with his own classification based on starch shape and hilum position. Karl Wilhelm von Nägeli (1817-1891) continued the study of the structure of starch (Britannica, 2016; Torrence, Barton, 2006). This Swiss botanist built on the work of J. M. Schleiden and created a modificaton of the starch-grain sorting system (Britannica, 2016), among others we could mention, such as Henry

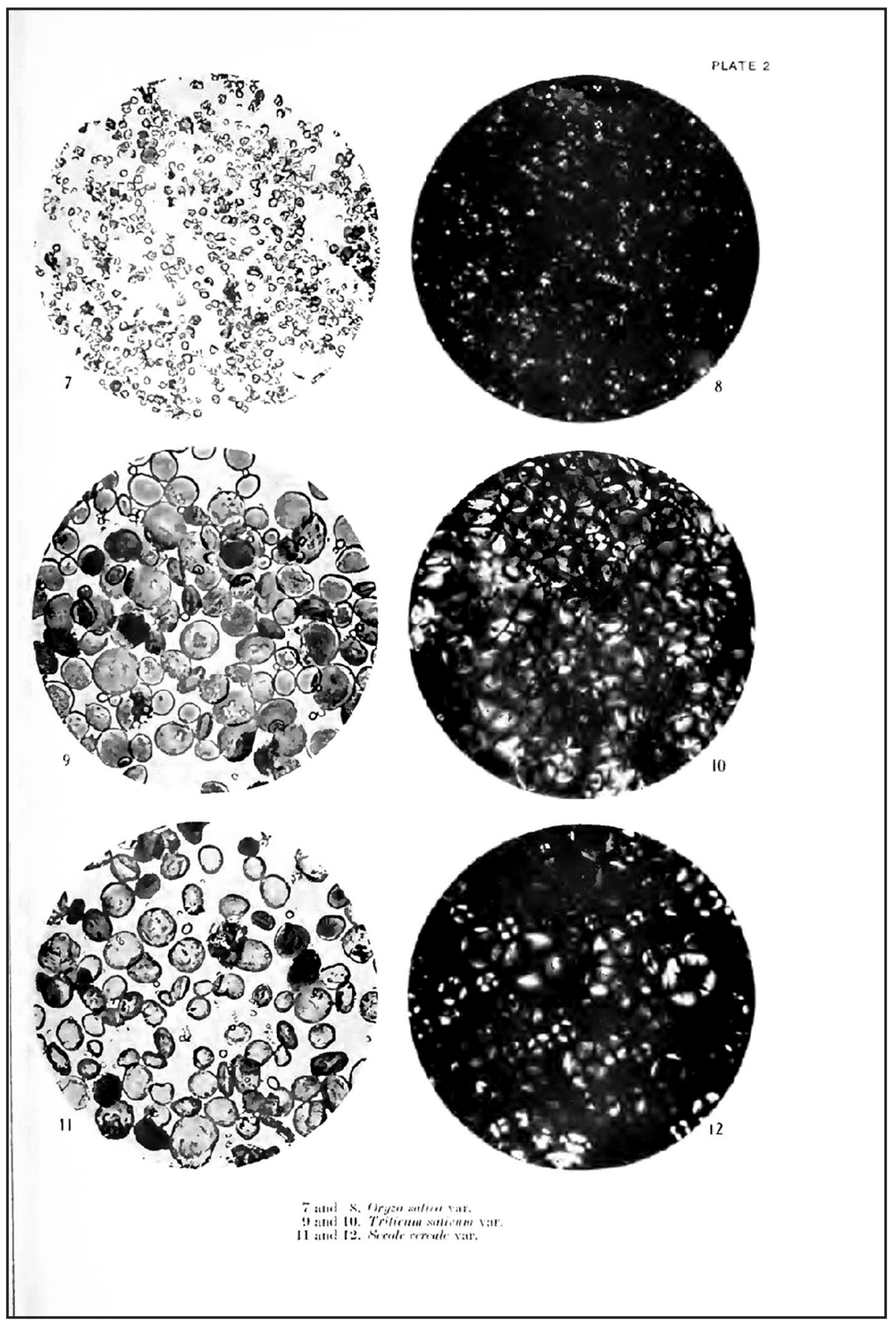

Figure 1. Illustration of Poaceae starch grain (Reichert, 1913). 
Kraemer (1868-1924) (Kraemer, 1907). Edward Tyson Reichert was a physiologist from Philadelphia who created a comprehensive work summarizing the knowledge of the study of starches (Figure 1), and described their properties and use for starch grain identification (Reichert, 1913; Torrence, Barton, 2006). These works found use in everyday life, especially in the pharmaceutical and food industries, where there was a need to check the quality and origin of food and plant products from medicinal plants. For example, in 1978, William Sedgwick Saunders (London's Medical Officer for Health) inspected the flour sold in London to prevent it being mixed with gypsum (Stevenson, 2014).

Subsequently, starch atlases were created to recognize individual species by noting differences in starch grains (Loy et al., 1992). Starch analysis has then been put into use in archaeological research over the last twenty-five years. In 2006, Robin Torrence and Huw Barton published a comprehensive account of starch analyses in archaeology (Torrence, Barton, 2006). One of the most prominent results of starch analysis connected with Stone Age artefacts can be traced to 2007, when the first results of the human plant diet at the Palaeolithic Gravettian site were published, describing the important role of plants in the Palaeolithic diet (Aranguren et al., 2007). Before Palaeolithic people were usually regarded as only hunters of large animals. In the last thirty years, we can see the expansion of starch studies in archaeology: as described in a recent account by Barton and Torrence (2015).

In this paper, we summarize some basic knowledge of starch analyses from the Palaeolithic, Mesolithic and Neolithic period. Our main focus is on the starch grain itself, its biology and mode of identification of stone implements in particular. A special section summarizes some of the results of starch analyses at specific archaeological sites and with certain objects.

\subsection{Starch}

Starch is a polysaccharide used as a reserve energy store in the majority of autotrophic plants. The exception is presented by the families Asteraceae, Campanulaceae, Liliaceae, and others, which store inuline as their reserve polysaccharide. Starch is a ready source of glucose for plants, suitable for long storage. It is a composition of two homopolysaccharides (amylose and amylopectine), originating from $\alpha$-D-glukopyranose. Amylose and amylopectine occur in a weight ratio of 1:3. In some crop plants, cultivars have been bred with an elevated one or the other component of starch (amylose or amylopectine) (Prugar, 2008). Amylose is a linear homoglycan consisting of up to 4500 (more often 1000-2000) glucose units. Amylopectine is a multiple-branched polysaccharide consisting of chains of 50,000-100,000 D-glucose units. Amylose is a linear $\alpha-\mathrm{D}(1-4)$-glucane of disaccharide maltose; the branching of the chain is limited to approximately ten loci per molecule (Velíšek, 1999; Bemiller, Whistler, 2009).

Starch is synthesised in the green parts of the plant - in the chloroplasts. There, small starch grains, about $1 \mu \mathrm{m}$ in diameter, which are called temporary or transitory starch, are created. These are further used or transported. Starch is further stored in special organelles - amyloplasts. Major quantities of starch are stored in reserve organs in specialized cells of the seeds, roots and tubers (Bemiller, Whistler, 2009). Premature fruits also contain starch, but with the ripening process the starch content decreases and in ripe fruits the starch hardly occurs. However, there are exceptions, such as bananas, where high amounts of starch are contained in the fruit (Velíšek, 1999). Starch is stored in amyloplasts in the form of starch grains, which are species-specific and differ in shape, size and polysaccharide ratio. These starch grain characteristics are, for the most part, given genetically, but are also influenced by external influences (Selvam, 2013). According to the crystallinity level of the granules, the starch can be divided into four forms, designated A, B, C and V. The variability is due to the internal spatial arrangement of the molecules. The most stable is form A, which occurs in cereals, and the least stable is form B, which is found in root crops and potatoes. The $\mathrm{C}$ form is characteristic of leguminous seeds (it is a mixture of starch form A and B), whereas gelatinized starches occur in the $\mathrm{V}$ form. From a chemical point of view, starch grains can also contain small quantities of other substances that occur in plant cells, such as proteins and lipids (Velíšek, 1999; Ahmed et al., 2016; Bemiler, Whister, 2009).

\subsection{Starch grain}

Starch granules occur in various shapes and sizes: round, kidney-shaped, oval-elongated and polygonal shapes are common. Granules can be separated or coagulated into aggregates. Starch grains also differ in size. It is possible to distinguish several structures and formations, all of which are used in the identification process. For example, the visibility and position of the hilum is observed: whether it is located in the centre of the starch granule or off-centre (Lentfer et al., 2002). Sometimes lamellas are visible. These are concentric lighter and darker stripes on the granule that are circular from the centre towards the starch edge (Czaja, 1969). They are more recognizable in larger starch grains and are connected to the gradual growth of starch grains. They can be divided into crystalline (a denser part) and semi-crystalline (a softer part with darker colouring). On the surface of starch grains, fissures or other superficial structures can be distinguished. Furthermore, the bevelling of the starch grain can be considered (Gott et al., 2006, Bemiller, Whistler, 2009). The effect of outside, natural or anthropogenic, influences on the starch granule can lead to its injury or even destruction (starch modification, swelling, gelatinization). Starch can be damaged mechanically (e.g. broken in the course of milling). A limiting factor for its preservation can be temperatures above $50^{\circ} \mathrm{C}$, when gelatinization takes place in the presence of water. The starch grain starts to deteriorate with exposure to enzymes, the effect of the amylase enzymatic group. Other harmful influences are, for example, long water exposure, low temperatures and charring (carbonization) (Messner et al., 2008; Lentger, 2012). 


\section{Methodology of starch analysis}

When the starch grain has a certain optical appearance, the starch can be identified with optical microscopy in polarized light by observing the extinction cross on the starch granule (Figure 2). Further approaches to starch identification encompass chemical methods and staining methods (Haslam, 2004). Lugol's solution stains the starch grains dark blue (Reichert, 1913). Using CongoRed colouring can be useful for identifying starch damaged by processing (e.g. cooking). After the pigment application, the starch turns red according to the degree of damage (Lamb, Loy, 2005). Another staining solution is Trypan blue. Trypan blue stains damaged starch grains and damaged starch that has a damaged natural shape, whereas undamaged starch granules do not stain. (Torrence, Barton, 2006) In some cases of archaeological investigation the various forms of starch do not stain well. The starch of individual (plant) genera and species can also be identified due to different rates of enzymatic decomposition or observing differences in their reaction with acids (Reichert, 1913). For the precise identification of starch grains, a specimen from a reference catalogue should be used (Haslam, 2004). A reference catalogue consists of starch grains from the individual parts of contemporary vegetation. It should contain samples from crop plants, medicinal plants, commercially-used plants and other important species occurring in the surrounding environment. Fresh samples considered for cataloguing should not be dried at temperatures higher than $35^{\circ} \mathrm{C}$. After drying they can be ground and used to create slides (Therin et al., 1997, Lentfer 2009, Hart, 2014). The prepared sample should be examined microscopically and described. Measured and detected values are then stored electronically, and the starch grains are also photographed. Results from the measurement and description of starch grains can then be employed in creating a statistical method of starch identification from archaeological samples, especially for determining statistically-significant traits and the correlation between them (Lentfer et al., 2002).

\subsection{Sampling of starch from archaeological objects}

Starch extraction is conducted by various means, most often with a pipette directly from the object's surface, or with the use of an ultrasonic bath. In the pipetting method a small quantity of distilled water is placed directly onto the surface of the examined object (Figure 3), though the place needs to be carefully selected. The most promising locations for starch grain conservation are scratches and fissures on the

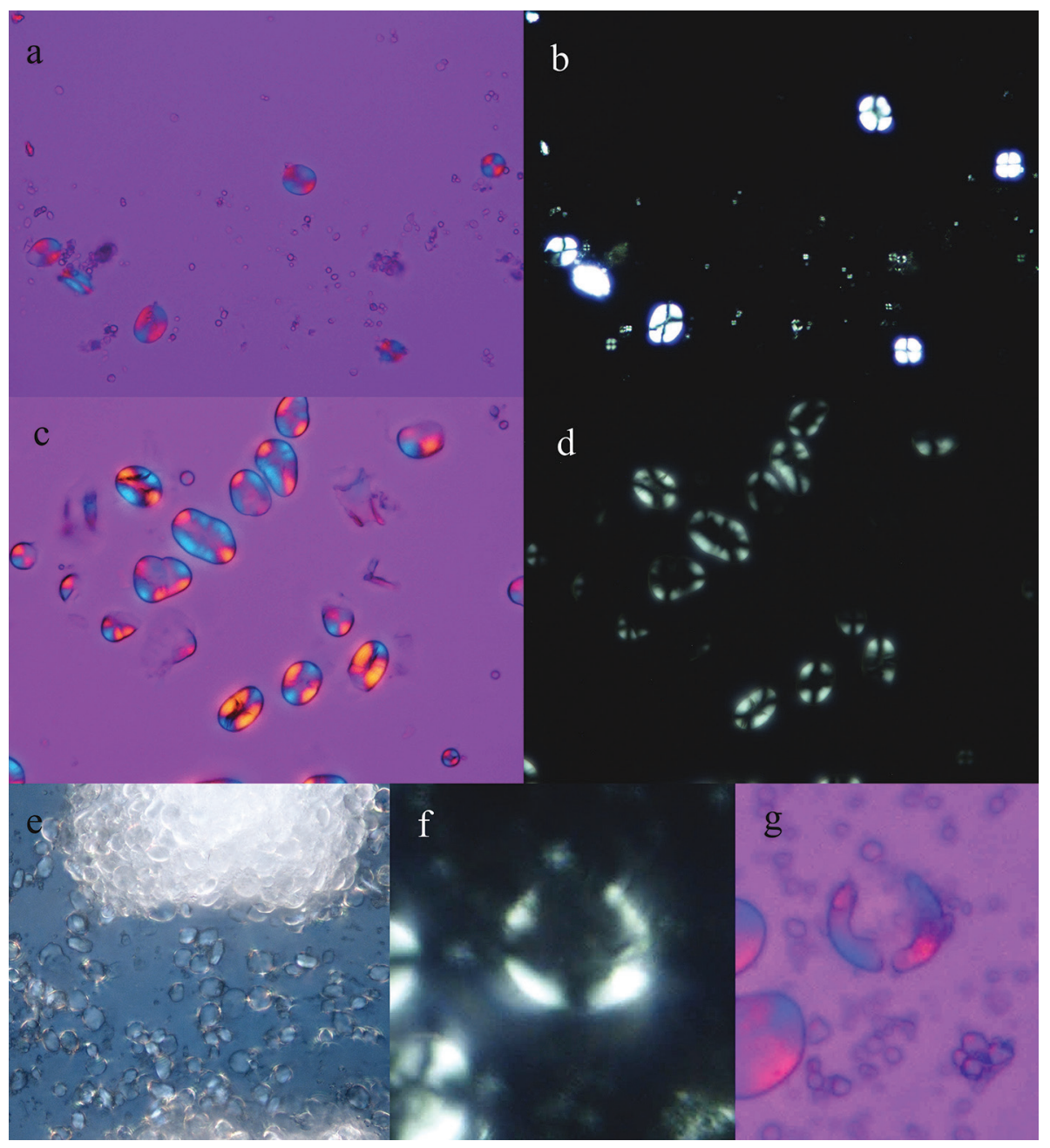

Figure 2. Recent grains under different lights (J. Kovárník) a, b) Starch grains from spring barely (Hordeum vulgare) in cross polarised light. c, d) Starch grins of Pisum sativum (Fabaceae) in cross polarised light. e) Starch grains from spring barley in normal light. f, g) Starch grain hydrolised by enzymes. 
Figure 3. Grinding stone from Hrdlovka, during sampling in the laboratory. (J. Kovárník).

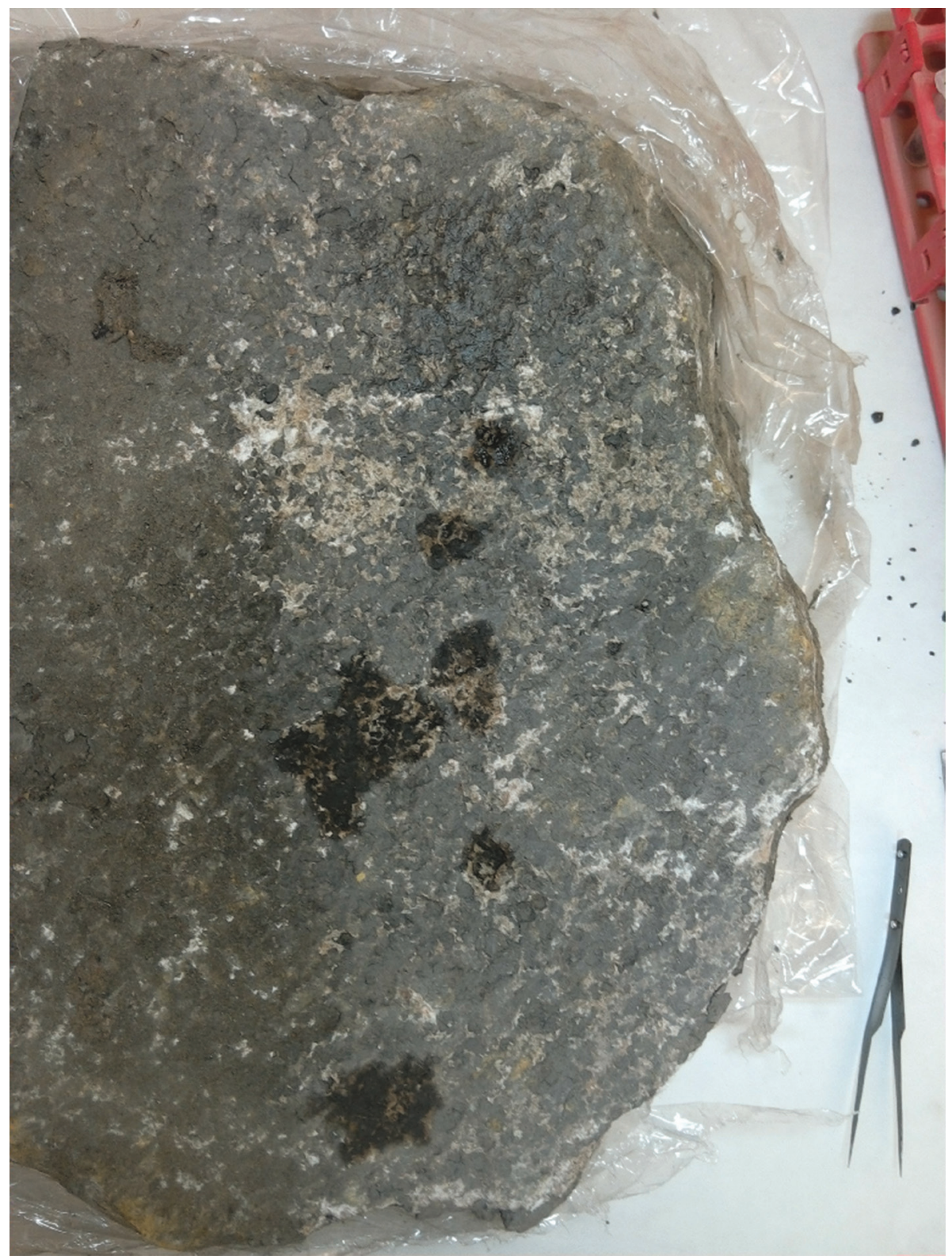

surfaces of various objects, or pores in the structure of dishes (Messner at al., 2008, Li et al., 2013; Pagán-Jiménez et al., 2015, Copeland, Hardy, 2018). The water drop containing the residues is collected by the pipette, from which it is possible to create a sample for microscopic analysis. This technique is suitable for determining the purpose and use of various objects and their individual parts ( $\mathrm{Li}$ et al., 2013; Tao et al., 2011; Yang et al., 2014; Yasui, 2015), allowing an examination of an object's specific function or mode of use. The other analytic approach is obtaining the sample from the examined object using sonication. The object is placed into a clean (sterile) beaker/test tube along with distilled water and the container inserted into the ultrasonic bath for five minutes. The distilled water with the relieved sample particles is transferred into a test tube and centrifuged at $2500 \mathrm{rpm}$ for 15 minutes. The excess solvent is then removed. Separation from the denser liquid $\left(\rho=1.8\right.$ g. $\left.\mathrm{cm}^{-3}\right)$ then takes place, the lighter fraction containing the starch grains coming to the surface with the heavier (mineral) fraction remaining on the test tube bottom. The mixture of sample and dense liquid is centrifuged for 5 minutes. After that the supernatant (approx. $2 \mathrm{ml}$ ) is extracted and subsequently diluted to make the starch grains form a sediment on the bottom. The microscopic sample can then be created (Messner at al., 2008; Liu et al., 2010; Marcadert et al., 2007). These techniques can, of course, be combined: it is possible to point-collect samples with the pipette and subsequently extract residues from the whole object in the ultrasonic bath (Lantos et al., 2015; Yang et al., 2015; Copeland, Hardy, 2018).

The extracted samples can be stored in a dry condition or in a tube with an ethanol solution (Therin et al., 1997). One way for making starch samples are by mounting on a microscopic slide using only water (in the case of temporary slides) or by storing dry samples of starch grains on a slide with a cover glass affixed using clear nail polish. This sample can be stored in a dry condition and a water drop can be added under the 
cover glass before observation. This method is simple and allows the observation of starch grains in polarized and nonpolarized light. It also allows repeated observations after drying and rehydration of the sample. (Piperno, 2006; Coil et al., 2003). Another way is to mount the sample in media to make a permanent preparation. Mounting media suitable for starch samples are glycerol (which can be diluted by water 1:1), Permount, Euparal, or immersion oil, etc., and the slide can then be sealed with clear nail polish (Yeung et al., 2015; Coil el al., 2003). However, Permount, for example, has some disadvantages: the optical properties of Permount do not allow the extinction cross to be observed on small starch grains. Starch placed into this medium for long periods also loses its typical refractions and slowly degrades. Starch has a refractive index of 1.52 to 1.53 ; for optimal observation in polarized light mounting media with a higher or lower refractive index than starch are suitable (Coil et al., 2003; Piperno, 2006; Wang et al., 2017).

\subsection{Sampling of starch from dental calculus}

Dental calculus is a layer that forms on teeth, especially on the tooth base. This layer is formed from biological plaque after mineralization. This material also contains other components such as organic materials or chemical components. It is a rich source of the tracks left by an ancient life style (Leclerc et al., 2018, Copeland, Hardy, 2018; Eerkens et al., 2018). Calculus must be carefully pulled down onto metal foil. After collection, the calculus is placed in a test tube with $0.6 \mathrm{M} \mathrm{HCL}$ for a short time. This step is for cleaning the calculus and for assuring whether it really is calculus or another sediment type. The next step is similar to the previous treatment, the dental calculus is dissolved in $\mathrm{HCl}$ for 5 days at a low temperature (Hardy et al., 2009). To speed up this extraction procedure it is possible to crush the larger parts of dental calculus and work with the resulting powder (Buckley et al., 2014). The final solution is vortexed, centrifuged at $15 \mathrm{~min}$, washed in ultra pure water and centrifuged again (three times) (Hardy et al., 2009). Another extraction possibility is using the ultrasonic bath (Hardy et al., 2012; Madella et al., 2014). A similar method for dental calculus is described by Cristiani et al., 2016.

\subsection{Sampling of starch from soil samples}

Starch grains can also be extracted from soils. This procedure can be complicated because it is necessary to take the soil samples from a specific place such as a pore, small depression or split/crack. However, in such locations there is a high probability of taking a rich sample. In below-ground conditions it is harder to preserve intact starch grains. In a field experiment that compared the survival rate of starch grains on grinding stones placed on the ground surface and below ground, it was shown that the samples taken from the experimental grinding stones on the soil surface contained better preserved starch grains (Barton, 2009; Vranová et al., 2015). Despite such observations, starch granules are well preserved at many archaeological sites (Fullagar et al., 1998; Therin et al., 1997). The first step for sample preparation is to dry the soil in the laboratory. After that, the process is similar to phytolith extraction including the heavy-liquid flotation procedure. For separating starch grain from sediment, a heavy liquid such as cesium chloride $(\mathrm{CsCl})$ or sodium polytungstate (SPT) should be used. Other chemicals with a high density can also be used. Starch grain analysis from soil samples can be usefully applied for land-use reconstruction (Dickau, et al., 2007; Balme, Beck, 2002; Parr, Carter, 2003).

\section{Starch identification}

Identification is carried out by direct observation and by comparison with specimens from the reference collection. In a vast collection the most important part is the thorough description of starch grains, as this will accelerate the comparison process (Cosgrove et al., 2007; Torrence et al., 2004; Hou et al., 2016). Direct observation can be accompanied by a statistical evaluation (Cosgrove et al., 2007; Herzog, 2014; Mayle, Iriarte, 2014), for example multi-dimensional analytic methods, which facilitate starch-grain identification from archaeological findings (Lentfer et al., 2002; Torrence et al., 2004). The next step would be automatic classification of starch grains provided by specialized software with Image analysis modules and statistics outputs. (Arráiz et al., 2016)

The sample must be prepared carefully and accurately in a clean laboratory environment and using only starch-free equipment and chemicals. It is good procedure to: control the level of contamination in the laboratory; add a control sample into the set of samples during the whole procedure; and examine the possibilities of transfer (Buffington et al., 2018). These simple precautions can reduce the risk of contamination, but not completely. Other ways to reduce contamination are complicated and expensive to purchase. Within this group can be included air filtration, sticky mats, restricted access, barrier curtains and airlocks (Crowther et al., 2014; Herzog, 2014; Ma et al., 2017).

\subsection{Microscopic structures that can look like starch}

In nature there exist several structures with similar optical properties to those of starch. Here is a list of common structures that look like starch: spherulites, fungal spores, bordered pits, damaged pollen, wall thickening, algae (diatoms and coccoliths), and microscopic air bubbles on the slide. Many of these structures are of the same size as a starch granule and make a similar optical signal under polarised light (Torrence, Barton, 2006). Two things that may help in differentiating between starch and non-starch structures are staining the starch grains (iodine staining) and rotating the birefringence extinction cross (Yeung et al., 2015; Moss, 1976).

\subsection{Implications of starch analysis in archaeological research of the Stone Age}

Perhaps the oldest identification of starch grains from the archaeological context of the Stone Age comes from Qesem 
Cave, Israel. The archaeological investigation revealed here eight hominid teeth in the context of the Amudian industry, which belongs to the blade-dominated Lower Palaeolithic Acheulo-Yabrudian Cultural Complex (AYCC) and predates the Middle Palaeolithic Mousterian traditions (400-250 ka, Hershkovitz et al., 2011;2016). The authors present evidence for potentially inhaled and ingested material in the dental calculus that was extracted from three of these teeth (Hardy et al., 2016). The identification of starch granules and specific chemical compounds in the dental calculus samples from Qesem Cave points to deliberate ingestion of essential dietary components, most likely in the form of concentrated sources such as seeds or nuts. The phytoliths and plant fibres found in the calculus could be the result of non-dietary activities, including raw material processing, oral hygiene or food remains.

Interesting evidence regarding a complex of starch grains was found in Shanidar Cave and Spy Cave (Henry et al., 2011), where the plant residues from tooth calculus originating from Neanderthal teeth were investigated. The two sets of samples were compared. The first came from Shanidar III, the Shanidar Cave in Iraq. The second set of samples came from Spy Cave in Belgium (Spy I and Spy II). In all, seven teeth were sampled: three teeth came from Shanidar III, two from Spy I and two from Spy II. The Shanidar Cave samples contained 73 starch grains, and the Spy Cave samples contained a total of 136 starch grains (Henry et al., 2011). The Spy Cave samples were 36,000 years old and the samples from Shanidar Cave were about 46,000 years old (Reader, 2011). In addition to the starch analysis, phytoliths were also analysed. With the results of both analyses completed, it was found that there had been heat modification of the plant food. The starch granules were typically damaged by heat. It is considered that largerscale plants were used, based on the seasonality of their maturation. Maturation is an important growing phase for maturing seeds or starch-rich organs, making them suitable for harvesting, storing and processing as food (Henry et al., 2011). An important message from this study is the direct evidence of plant use among the Neanderthals and the role of plants in their subsistence, a group traditionally regarded as strongly dependent on hunted animals. The results show the difference in diet caused by the different environments. But Neanderthals from both the sites had a quite varied diet (grass seeds, plant underground-storage organs, legumes, and dates). Henry found that Neanderthals were adaptable, had good knowledge about their surroundings, and used their environment very effectively. This is highlighted by their complicated food behaviour, including heat preparation of food for better digestibility. The data collected from sediment could not clearly show which plant material was used for food. Calculus micro-analysis can also be used for ancient diet reconstruction. The results from the calculus analysis also showed that samples taken from different teeth from the same person could provide significantly different amounts of information. Two teeth from the same individual were compared: the calculus from the first tooth contained a large amount of starch grains, while the second tooth was poor in starch grains. This comparison was made at the Spy I site and repeated at Spy II with the same result. The subsistence of Neanderthals seems to be much more balanced given the perspective of starch analysis.

Starch analysis had already been used effectively in a series of entire archaeological studies of the Gravettian population belonging already to Homo sapiens. Residue analyses on a grinding tool from Grotta Paglicci in southern Italy $(32,614 \pm 429$ calibrated (cal) BP), recorded rich assemblages of starch grains, most probably of Avena (oat) caryopses, and this has substantially enriched our knowledge concerning the food plants of Palaeolithic Europe in the context of the Early Gravettian period (Lippi et al., 2015). The quantitative distribution of the starch grains on the surface of the grinding stone furnished information about the tool being used as a pestle grinder. The particular state of preservation of the starch grains suggests the use of thermal treatment before grinding, possibly to accelerate the drying of the plants, making the following process easier and faster (Lippi et al., 2015). One of the most important results of starch analysis in archaeology has been made in the case of Gravettian (the Upper Palaeolithic period) site Bilancino. The authors have identified starch grains on the surface of a grinding stone from the hunter-gatherer campsite of Bilancino (Florence, Italy), dated to around 25,000 BP. Analysis has identified the remains of starches of the wild plants Typha and Graminae cf. Brachypodium. The stone can be seen as a grindstone and the starch has been extracted from locally-growing edible plants. This evidence can be claimed as implying the making of flour - and presumably some kind of bread - some 15 millennia before the local “agricultural transition" (Aranguren et al., 2007).

The above-mentioned study from Grotta Paglicci, Bilancino, and other archaeological sites like the Upper Gravettian site Dolní Věstonice, clearly indicate the predisposition of Upper Palaeolithic modern humans for sophisticated plant exploitation long before the spread of agricultural knowledge (Revedin et al., 2010; 2015). The last decade of research has fundamentally changed our view on how the Paleolithic people exploited plants. Phytolithic studies, the analysis of starch granules on stone tools, as well as isotopic and nutritional studies, have newly demonstrated the significant role of plant food in their diet (Beneš, 2018).

This picture seems to be confirmed by micro-remains analyses of starch from the Palaeolithic period from other regions of the world. Interesting evidence of ancient starch has been published by Loy et al. (1992), who presented residue analysis of stone artefacts from the Solomon Islands. This study described the use of starch analysis on a set of stone tools from Kilu Cave on Buku Island (Solomon Islands in Melanesia). In the Kilu Cave profile, evidence was found of a dual settlement, the oldest occupation being dated at 28,000 years old. Starch analysis was used as direct evidence of the spread of plant species and to specify the use of tools. In all, a set of 47 stone tools and fragments were examined, twenty of them showing no trace of starch grains. Of the 
27 tools that contained starch grains, 8 stone tools came from younger layers and 17 stone artefacts from older layers (up to 28,000 years old). Stone artefacts from the older layers contained starch grains derived from plants of the Colocasia and Alocasia genera (Loy et al., 1992). This micro-remains evidence supports our view of the balanced role of plants in the local Palaeolithic diet in Oceania, despite the fact that the tropical environment of the Solomon Islands favoured a plant-based subsistence in general (Bellwood, 2005).

The Late Palaeolithic and Early Neolithic archaeobotanical knowledge from China concerning starch analysis is very important. China belongs to the centres of agricultural beginnings (Bellwood, 2005; Barker, 2006; Beneš, 2018), where a vast amount of archaeobotanical research has been recorded in the last decade. China has a large area that includes boreal landscape and semi-deserts in the north of the country, temperate deciduous forests, and regions of subtropical forests in southern China. The two key developments of the Epipalaeolithic and Early Neolithic centres were situated in the middle Yangtze basin and in the upper and middle Yellow River Basin of northern China. A functional study of two grinding stones (a slab and a grinding stone) near a burial dated to $9220-8750 \mathrm{BC}$ cal. (before the onset of the Neolithic), at Donghulin, investigated the range of plants exploited during this early occupation period. Starch residues indicate that the grinding stones were used for processing plants, and confirm the processing of acorns, which is consistent with the incidence of oak (Quercus) in the pollen record (Liu et al., 2010b). Similar observations concerning a younger period have been made in the case of the Early Neolithic Peiligang culture sites Shigou and Egou in the catchment of the Yellow River, where starch analysis on grinding stones has documented the presence of acorns and other plants, probably Cyclobalanopsis, Lithocarpus, Dioscorea, Trapa and others (Liu et al., 2010a). The abovementioned examples indicate the unchanged plant processing customs of people in the Late Palaeolithic and Early Neolithic period reflecting a continual development from a huntergatherer economy to the stages of early agriculture. The use of archaeological artefacts in this context plays an important bioindicative role as indicated by the starch analysis.

In recent years some new observations have been made in the field of Stone Age research concerning Mesolithic and Neolithic Europe. The most interesting evidence associated with starch grains has been made during an investigation of the dental calculus of Mesolithic human teeth at the site of Vlasac in the Danube Gorges of the central Balkans (Cristiani et al., 2016). The research has provided direct evidence that already by $6600 \mathrm{cal}$. BC, if not earlier, the Late Mesolithic foragers here consumed domestic cereals, such as Triticum monococcum, Triticum dicoccum, and Hordeum distichon. These plant species were the main crops found among the Early Neolithic communities of southeast Europe. This investigation indicates the great value of starch grain identification in the Mesolithic human population and their interaction with the Neolithic people from the southernmost Balkans several centuries before the Neolithic package of domesticated plants and (probably) Neolithic people reached the inland areas of the Balkans around 6200-6000 BC cal (Kreuz et al., 2005; Brami, 2017).

Another interesting example, again from the Balkan region, combines starch and phytolith analysis. At the late Middle and early Late Neolithic site of Stavroupoli, Thessaloniki, Greece, a series of organic remains from ceramic sherds were studied. The research focused on matter recovered from cooking vessels, where charred food crusts had adhered to the inner walls of 17 late Middle and early Late Neolithic vessels (ca. 5600-5000 BC cal.). Starch grains were very scarce or absent in most of the samples, but samples ST129 and ST192 presented a high concentration of small Panicoideae and Triticeae grains (García-Granero et al., 2017), as well as big and small types of Panicoideae. With supporting phytolith analysis, the research authors concluded that the analysis of starch grains and phytoliths from charred food crust on the ceramics added valuable information to previous studies on the diet in Neolithic Stavroupoli. Especially remarkable is the identification of the use of the potentially wild weed Setaria in the diet.

Research of starch remains was also successful in the central European Neolithic context. In TiszaszigetAgyagbánya in southeastern Hungary, a site belonging to the Late Neolithic Tisza culture (ca. 5000-4500 BC cal.) was investigated. Here in a pit associated with postholes - the remains of a longhouse - three intact vessels and one grinding stone were unearthed. The layout of objects in the pit evokes its ritual character. The unearthed vessels were situated in the hole of the former central post of the building's structure. The subject of interest by microscopic and biochemical analysis was organic matter from the bottom of the vessels. The methods used were complex, including the study of phytoliths, starch and biochemical signals (Petö et al., 2013). Phytolithic morphologies present in the samples have their anatomical origin from the leaf and inflorescence of Poaceae (as well as cereals). Among the phytoliths, which indicate the predominance of grasses, five partly-damaged starches were observed. Based on their identification, the starches from the sample most likely represent wheat (Triticum sp.).

Starch analysis has been carried out in the case of a set of grinding stones from the Neolithic site of Hrdlovka (Northwest Bohemia, Czech Republic). The samples were taken from grindstones deposited in feature 838 and dated to $4620-4458 \mathrm{BC}$ cal. and were situated in the area of house 8 from the Late SBK period. The deposition of millstones could have a ritual or social meaning connected with the foundation of the house. Altogether 8 grinding stones were analysed for the presence of starch grains and their surfaces revealed 49 starch grains (Beneš et al., 2015). Overall, it was possible to determine 12 circular starch grains as belonging to plants of the family Poaceae. Starch grains of an oval shape with the characteristic extinction cross belonged to the family Fabaceae. Determination of starch grains from the Neolithic Hrdlovka site represents the first such positive analysis of micro-remains in the Czech Republic. 
The last above-mentioned examples from central Europe represent cases of a similar archaeological situation, where artefacts from sunken features dating to the Neolithic period played a central role, as well as a specific, possibly ritual, meaning for both artefact deposits. In both cases starch analysis contributed to specifying their role in the Neolithic community.

\section{Conclusion}

Starch grain analysis is a useful tool for evaluating archeobotanical specimens from soil samples, artefacts, and from human teeth. Using starch grain analysis, it is possible to identify plants that are in a non-flowering growth phase and would not be identified by pollen analysis. A further great advantage is that humans preferred plants with a large amount of starch. Those plants, and their individual organs with a high starch content, were used as energy sources from human nutrition. People used and processed a lot of material that can be identified in archaeological contexts. However, for the same reason, there is a risk of contamination of the sample from present-day materials containing starch grains. Unfortunately, starch grains are relatively susceptible to environmental conditions, such as those not of optimal temperature and neutral $\mathrm{pH}$. Another disadvantage is the inability to capture plants from the family Asteraceae, as they do not form starch but inulin. Starch grain analysis is more effective in combination with other bioarchaeological methods, such as pollen, phytolith determinations and analysis of botanical macroremains. Hence the method of starch analysis is also notably useful in combination with biochemical analysis targeted at a specific group such as amino acids or lipids.

In general, starch analysis constitutes a useful tool in bioarchaeological investigations. Despite its relatively limited taxonomical power, it is an effective supporting method in the functional determination of artefacts such as millstones and grinders, and a key source of information in the bioarchaeological research of food remains on pottery. It is also possible to point towards the propagation, use and processing of plant species. The anthropological application of this method targeted on dental calculus is also particularly important. Current studies of these biological traces have shed new light on the ratios between meat- and plant-based diets. Some results clearly indicate a higher ratio of plant diets among Palaeolithic human populations than previously thought. In future research, starch analysis - together with pollen and phytolith analyses - will form a crucial basis for functional bioarchaeological interpretation.

\section{Acknowledgements}

This article was supported by the OPVK project PAPAVER - Centre for human and plant studies in Europe and Northern Africa in the post-glacial period, registration no. CZ.1.07/2.3.00/20.0289.

\section{References}

AHMED, J., TIWARI, B.K., IMAM, S. H., and RAO, M.A., 2016. Starchbased polymeric materials and nanocomposites: Chemistry, processing, and applications. Boca Raton: Taylor \& Francis Group.

ALBERT, R.K., KOOIMAN, S.M., CLARK, C.A., and LOVIS, W.A., 2018. Earliest microbotanical evidence for maize in northern Lake Michigan basin. American Antiquity, 83(2), 345-355.

ARANGUREN, B., BECATTINI, R., MARIOTTI LIPPI, M., and REVEDIN, A., 2007. Grinding flour in Upper Palaeolithic Europe (25,000 years bp). Antiquity, 81, 845-855.

ARRÁIZ, H., BARBARIN, N., PASTUREL, M., BEAUFORT, L., DOMÍNGUEZ-RODRIGO, M., and BARBONI, D., 2016. Starch granules identification and automatic classification based on an extended set of morphometric and optical measurements. Journal of Archaeological Science: Reports, 7, 169-179.

BALME, J., BECK, W.E., 2002. Starch and charcoal: useful measures of activity areas in archaeological rockshelters. Journal of Archaeological Science, 29(2), 157-166.

BARTON, H., 2009. Starch granule taphonomy: the results of a two year field experiment. In: Archaeological Science Under a Microscope: Studies in Residue and Ancient DNA Analysis in Honour of Tom Loy, 129-140. Canberra.

BARTON, H., and TORRENCE, R., 2015. Cooking up recipes for ancient starch: Assessing current methodologies and looking to the future. Journal of Archaeological Science, 56, 194-201.

BARTON, H., and WHITE, P.J., 1993. Use of Stone and Shell Artifacts at Balof 2, New Ireland, Papua New Guinea. Asian perspectives, 32(2), 169-81.

BEMILLER, J.N., and WHISTLER, R.L., 2009. Starch: chemistry and technology. $3^{\text {rd }}$ ed. Amsterdam: Academic Press.

BELlWOOD, P., 2005. First Farmers. The Origins of Agricultural Societies. Oxford: Blackwell Publishing.

BENEŠ, J., 2018. Počátky zemédělstvi ve Starém světě - The origins of agriculture in the Ancient World. České Budějovice: Episteme.

BENEŠ, J., VONDROVSKÝ, V., ŠÍDA, P., DIVIŠOVÁ, M., KOVAČIKOVÁ, L., KOVÁRNÍK, J., and VAVREČKA, P., 2015. The Rare Deposition of Neolithic (SBK) Grinding Tools and Longhouse 8 from Hrdlovka (Czech Republic): Analysis and 3D Virtual Reconstruction. Interdisciplinaria Archaeologica. Natural Sciences in Archaeology, 6(2), 161-179.

BRAMI, M.N,. 2017. The Diffusion of Neolithic Practices from Anatolia to Europe. A contextual study of residential construction, 8,500-5,500 BC cal. Oxford: BAR International Series.

BUCKLEY, S., USAI, D., JAKOB, T., RADINI, A., HARDY, K., and GUATELLI-STEINBERG, D., 2014. Dental Calculus Reveals Unique Insights into Food Items, Cooking and Plant Processing in Prehistoric Central Sudan. PLOS ONE, 9/7.

BUFFINGTON, A. F., WEILAND, A., ARNOLD, J., and ARBOGAST, D., 2018. What is Your "Phytolith Load"? An Examination of the Potential for Cross-Contamination During Phytolith Extraction. Ethnobiology Letters, 9(2), 65-74.

CAGNATO, C., 2018. Shedding Light on the Nightshades (Solanaceae) Used by the Ancient Maya: a Review of Existing Data, and New Archeobotanical (Macro-and Microbotanical) Evidence from Archeological Sites in Guatemala. Economic Botany, 1-16.

COIL, J., KORSTANJE, M.J., ARCHER, S., and HASTORF, C.A., 2003. Laboratory goals and considerations for multiple microfossil extraction in archaeology. Journal of Archaeological Science, 30, 991-1008.

COPELAND, L., and HARDY, K., 2018. Archaeological Starch. Agronomy, $8(1), 4$.

CORTELETTI, R., DICKAU, R., DEBLASIS, P., and IRIARTE, J., 2015. Revisiting the economy and mobility of southern proto-Jê (TaquaraItararé) groups in the southern Brazilian highlands: starch grain and phytoliths analyses from the Bonin site, Urubici, Brazil. Journal of Archaeological Science, 58, 46-61.

COSGROVE, R., FIELD, J., and FERRIER, A., 2007. The archaeology of Australia's tropical rainforests. Palaeogeography, Palaeoclimatology, Palaeoecology, 251(1), 150-173.

CRISTIANI, E., RADINI, A., EDINBOROUGH, M. and BORIĆ, D., 2016. 
Dental calculus reveals Mesolithic foragers in the Balkans consumed domesticated plant foods. Proceedings of the National Academy of Sciences of the United States of America, 113(37), 10298-10303.

CZAJA, A.T., 1969. Die Mikroskopie der Stärkekörner. In: Handbuch der Stärke in Einzeldarstellungen. Berlin.

D'ANDREA, A.C., FAHMY, A.G., PERRY, L., RICHARDS, M.P., DARCUS, L., TOFFOLO, M., and ATTIA, E.S.A., 2015. Ancient agricultural economy in the Horn of Africa: new evidence from grinding stones and stable isotopes. SUPPLEMENTO VOL. CXL, 155.

DENHAM, T.P., HABERLE, S.G., LENTFER, C., FULLAGAR, R., FIELD, J., THERIN, M., PORCH, M. and WINSBOROUGH, B., 2003. Origins of agriculture at Kuk Swamp in the highlands of New Guinea. Science, 301(5630), 189-193.

DICKAU, R., RANERE, A.J., and COOKE, R.G., 2007.Starch grain evidence for the preceramic dispersals of maize and root crops into tropical dry and humid forests of Panama. Proceedings of the National Academy of Sciences, 104(9), 3651-3656.

EERKENS, J.W., TUSHINGHAM, S., BROWNSTEIN, K.J., GARIBAY, R., PEREZ, K., MURGA, E., KAIJANKOSKI, P., ROSENTHAL, J.S., and GANG, D.R., 2018. Dental calculus as a source of ancient alkaloids: Detection of nicotine by LC-MS in calculus samples from the Americas. Journal of Archaeological Science: Reports, 18, 509-515.

EVANS, J., and O'CONNOR, T., 1999. Environmental Archaeology. Stroud.

EVANS, J.G., and RITCHIE, G., 2005. New light on the earliest Neolithic in the Dee Valley, Past, 50, 1-6.

FULlAGER, R., LOY, T., and COX, S., 1998. Starch Grains, Sediments, and Stone Tool Function: Evidence from Bitokara, Papua New Guinea. In: R. Fullager, ed. A Closer Look: Recent Australian Studies of Stone Tools. Sydney: Sydney University. 49-60.

FULlER, D.Q., DENHAM, T., ARROYO-KALIN, M., LUCAS, L., STEVENS, C.J., QIN, L., ALLABY, R.G., and PURUGGANAN, M.D., 2014. Convergent evolution and parallelism in plant domestication revealed by an expanding archaeological record. Proceedings of the National Academy of Sciences, 111(17), 6147-6152.

GARCÍA-GRANERO, J., LANCELOTTI, C., and MADELLA, M.A., 2015. Tale of multi-proxies: integrating macro-and microbotanical remains to understand subsistence strategies. Vegetation History and Archaeobotany, 24(1), 121-133.

GARCÍA-GRANERO, J.J., UREM-KOTSOU, D., BOGAARD, A., and KOTSOS, S., 2017. Cooking plant foods in the northern Aegean: Microbotanical evidence from Neolithic Stavroupoli (Thessaloniki, Greece). Quaternary International, (in press).

GOTT, B., BARTON, H., SAMUEL, D., and TORRENCE, R, 2006. Biology of starch. In: R. Torrence and H. Barton. Ancient starch research. Walnut Creek, Calif.: Left Coast Press, pp. 35-45.

HALL, J., HIGGINS, S., and FULLAGER, R., 1989. Plant residues on stone tools. In: W. Beck, A. Clarke, L. Head, eds. Plants in Australian Archaeology. Brisbane: University of Queensland, pp. 136-160.

HARDY, K., BLAKENEY, T., COPELAND, L., KIRKHAM, J., WRANGHAM, R, and COLLINS, M., 2009. Starch granules, dental calculus and new perspectives on ancient diet. Journal of Archaeological Science, 36(2), 248-255.

HARDY, K., BUCKLEY, S., COLLINS, M.J., ESTALRRICH, A., BROTHWELL, D., COPELAND, L., GARCÍA-TABERNERO, A., GARCÍA-VARGAS, S., RASILLA, M., LALUEZA-FOX, C., HUGUET, R., BASTIR, M., SANTAMARÍA, D., MADELLA, M., WILSON, J., CORTÉS, A.F., and ROSAS, A., 2012. Neanderthal medics? Evidence for food, cooking, and medicinal plants entrapped in dental calculus. Naturwissenschaften, 99(8), 617-626.

HARDY, K., RADINI, A., BUCKLEY, S., SARIG, R., COPELAND, L., GOPHER, A., and BARKAI, R., 2016. Dental calculus reveals potential respiratory irritants and ingestion of essential plant-based nutrients at Lower Palaeolithic Qesem Cave Israel. Quaternary International, 398, 129-135.

HART, T.C., 2014. Analysis of Starch Grains Produced in Select Taxa Encountered in Southwest Asia. Ethnobiology Letters, 5, 135-145.

HENRY, A.G., BROOKS, A.S., and PIPERNO, D.R., 2011. Microfossils in calculus demonstrate consumption of plants and cooked foods in Neanderthal diets (Shanidar III, Iraq; Spy I and II, Belgium). Proceedings of the National Academy of Sciences, 108(2): 486-491.
HERSHKOVITZ, I., SMITH, P., SARIG, R., QUAM, R., RODRIGUEZ, L., GARCIA, R., ARSUAGA, J.L., BARKAI, R., and GOPHER, A., 2011. Middle Pleistocene dental remains from Qesem Cave (Israel). American Journal of Physical Anthropology, 144(4), 575-592.

HERZOG, N.M., 2014. Starch grain analysis in California and the Great Basin. California Archaeology, 6(2) 171-189.

HIGGINS, S., 1988. Starch grain differentiation on archaeological residues: a feasibility study. St. Lucia, Qld.

HOGG, J., 1854. The microscope: Its history, construction, and applications. Illustrated London Library.

HOU, G., MA, Z., CHONGYI, E., ZHANG, W., and Wei, H, 2016. Plant utilization at the Jiangxigou site during the middle Holocene. Archaeological Research in Asia, 5, 54-62.

JACOMET, S., and KREUZ, A., 1999. Archäobotanik. Aufgaben, Methoden und Ergebnisse vegetations- und agrargeschichtlischer Forschung. Stuttgart: UTB.

KISLEV, M.E.A., 1986. Barley store of the Bar-Kochba rebels (Roman period). Israel Journal of Botany, 35(3-4), 183-196.

KRAEMER, H., 1907. A Text-book of Botany and Pharmacognosy. Philadelphia, London. Lippincott.

KREUZ, A., MARINOVA, E., SHÄFER, E., and WIETHOLD, J., 2005. A comparison of early Neolithic crop and weed assemblages from the Linearbandkeramik and the Bulgarian Neolithic cultures: differences and similarities. Vegetation History and Archaeobotany, 14, 237-258.

LAMB, J., and LOY, T., 2005. Seeing red: the use of Congo Red dye to identify cooked and damaged starch grains in archaeological residues. Journal of Archaeological Science, 32(10), 1433-1440.

LANTOS, I., SPANGENBERG, J.E., GIOVANNETTI, M.A., RATTO, N., and MAIER, M.S., 2015. Maize consumption in pre-Hispanic south-central Andes: chemical and microscopic evidence from organic residues in archaeological pottery from western Tinogasta (Catamarca, Argentina). Journal of Archaeological Science, 55, 83-99.

LECLERC, M., TACHÉ, K., BEDFORD, S., SPRIGGS, M., LUCQUIN, A., and CRAIG, O.E., 2018. The use of Lapita pottery: Results from the first analysis of lipid residues. Journal of Archaeological Science: Reports, 17, 712-722.

LENTFER, C, THERIN, M., and TORRENCE, R., 2002. Starch Grains and Environmental Reconstruction: a Modern Test Case from West New Britain, Papua New Guinea. Journal of Archaeological Science, 29, 687-698.

LENTFER, C.J., 2009. Building a comparative starch reference collection for Indonesia and its application to palaeoenvironmental and archaeological research. In: M. Haslam, ed. Archaeological science under a microscope: studies in residue and ancient DNA analysis in honour of Thomas H. Loy. Canberra, ACT: ANU E Press, pp. 80-101.

LOY, T.H., SPRIGGS, M., and WICKLER, S., 1992. Direct evidence for human use of plants 28,000 years ago: starch residues on stone artefacts from the northern Solomon Islands. Antiquity, 66, 898-912.

LI, M., YANG, X., GE, Q., REN, X., and WAN, Z., 2013. Starch grain analysis of stone knives from Changning site, Qinghai Province, Northwest China. Journal of Archaeological Science, 40(4), 1667-1672.

LIPPI, M.M., FOGGI, B., ARANGUREN, B., RONCHITELLI, A., REVEDIN, A., and BAR-YOSEF, O., 2015. Multistep food plant processing at Grotta Paglicci (Southern Italy) around 32,600 cal B.P. Proceedings of the National Academy of Sciences of the United States of America, 112(39), 12075-12080.

LIU, L., FIELD, J., FULLAGAR, R., ZHAO, Ch., CHEN, X., and YU, J., 2010. A functional analysis of grinding stones from an early holocene site at Donghulin, North China. Journal of Archaeological Science, 37(10), 2630-2639.

LIU, L., FIELD, J., FULLAGAR, R., BESTEL, S., CHEN, X. and MA, X., 2010. What did grinding stones grind? New light on Early Neolithic subsistence economy in the Middle Yellow River Valley, China. Antiquity, 84(325), 816-833.

LÓPEZ, M.L., 2018. Archaeobotany in central Argentina: macro-and microscopic remains at several archaeological sites from early Late Holocene to early colonial times (3,000-250 bp). Vegetation History and Archaeobotany, 27(1), 219-228.

MA, Z., ZHANG, C., LI, Q., PERRY, L., and YANG, X., 2017. Understanding the Possible Contamination of Ancient Starch Residues by Adjacen Sediments and Modern Plants in Northern China. Sustainability, 9(5), 752. 
MADELLA, M., GARCÍA-GRANERO, J.J., OUT, W.A., RYAN, P., and USAI, D., 2014. Microbotanical evidence of domestic cereals in Africa 7000 years ago. PLOS ONE, 9(10).

MAYLE, F.E., and IRIARTE, J., 2014. Integrated palaeoecology and archaeology-A powerful approach for understanding pre-Columbian Amazonia. Journal of Archaeological Science, 51, 54-64.

MERCADER, J., BARTON, H., GILLESPIE, J., HARRIS, J., KUHN, S., TYLER, R., and BOESCH, C., 2007. 4,300-year-old chimpanzee sites and the origins of percussive stone technology. Proceedings of the National Academy of Sciences, 104(9), 3043-3048.

MESSNER, T. C., DICKAU, R., and HARBISON, J., 2008. Starch Grain Analysis: Methodology and Applications in the Northeast. In: J.P. Hart, ed. Current Northeast paleoethnobotany II. Albany, N.Y.: University of the State of New York, State Education Dept, pp. 111-128.

MOSS, G.E., 1976. The microscopy of starch. In: J.A. Radley, ed. Examination and analysis of starch and starch products. Netherlands: Springer, pp. 1-32.

PAGÁN-JIMÉNEZ, J.R., RODRÍGUEZ-RAMOS, R., REID, B.A., VAN DEN BEL, M., and HOFMAN, C.L., 2015. Early dispersals of maize and other food plants into the Southern Caribbean and Northeastern South America. Quaternary Science Reviews, 123, 231-246.

PARR, J.F., and CARTER, M., 2003. Phytolith and starch analysis of sediment samples from two archaeological sites on Dauar Island, Torres Strait, northeastern Australia. Vegetation History and Archaeobotany, 12(2), 131-141.

PESTLE, W.J., and LAFFOON, J., 2018. Quantitative paleodietary reconstruction with complex foodwebs: An isotopic case study from the Caribbean. Journal of Archaeological Science: Reports, 17, 393-403.

PETÖ, Á., GYULAI, F., PÓPITY, D., and KENÉZ, Á., 2013. Macroand micro-archaeobotanical study of a vessel content from a Late Neolithic structured deposition from southeastern Hungary. Journal of Archaeological Science, 40(1), 58-71.

PIPERNO, D.R., 2006. Phytoliths: A Comprehersive Guide for Archaeologists and Paleoecologists. Rowman Altamira.

PRIMAVERA, M., HEISS, A.G., VALAMOTI, M.S., QUARTA, G., MASIERI, M., and FIORENTINO, G., 2018. Inside sacrificial cakes: plant components and production processes of food offerings at the Demeter and Persephone sanctuary of Monte Papalucio (Oria, southern Italy). Archaeological and Anthropological Sciences, 1-15.

PRUGAR, J., 2008. Kvalita rostlinných produktio na prahu 3. tisíciletí. Praha: Výzkumný ústav pivovarský a sladařský ve spolupráci s Komisí jakosti rostlinných produktů ČAZV.

READER, J., 2011. Missing links: in search of human origins. $1^{\text {st }}$ ed. Oxford: OUP Oxford.

REICHERT, E.T., 1913. The Differentiation and Specificity of Starches in Relation, to Genera, Species. London.

REVEDIN, A., ARANGUREN, B., BECATTINI, R., LONGO, L., MARCONI, E., LIPPI, M.M., SKAKUN, N., SINITSYN, A., SPIRIDONOVA, E., and SVOBODA, J., 2010. Thirty thousand-year-old evidence of plant food processing. Proceedings of the National Academy of Sciences, 107(44), 18815-18819.

REVEDIN, A., LONGO, L., MARIOTTI LIPPI, M., MARCONI, E., RONCHITELLI, A., SVOBODA, J., ANICHINI, E., GENNAI, M., and
ARANGUREN, B., 2015. New technologies for plant food processing in the Gravettian. Quaternary International, 359, 77-88.

ROOSEVELT, A.C., 2016. Method and Theory of Early Farming: The Orinoco and Caribbean Coasts of South America. Earth Science Research, 6(1)

SELVAM, A.B.D., 2013. Standardization of Descriptive terminology of starch granules with reference to identification of raw drugs. International Journal of Pharmaceutical Research and Development, 5(7), 1-6.

SHILLITO, L.M., BLONG, J.C., JENKINS, D.L., STAFFORD J.R., T.W., WHELTON, H., MCDONOUGH, K., and BULL, I.D., 2018. New Research at Paisley Caves: Applying New Integrated Analytical Approaches to Understanding Stratigraphy, Taphonomy and Site Formation Processes. PaleoAmerica, 1-5.

STEVENSON, B., 2014: Adulterated Flour, London, January, 1879. [online]. [viewed 18/11/2017]. Avalible from http://microscopist.net/ MansionHouseFlour.htm

TAO, D., WU, Y., GUO, Z., HILL, D.V., and WANG, C., 2011. Starch grain analysis for groundstone tools from Neolithic Baiyinchanghan site: implications for their function in Northeast China. Journal of Archaeological Science, 38(12), 3577-3583.

THERIN, M.; TORRENCE, R., and FULLAGAR, R., 1997. Australian Museum Starch Reference Collection. Australian Archaeology, 44, $52-53$

TORRENCE, R., WRIGHT, R. and CONWAY, R., 2004. Identification of starch granules using image analysis and multivariate techniques. Journal of Archaeological Science, 31(5), 519-532.

TORRENCE, R., and BARTON, H., 2006. Ancient Starch Research. Walnut Creek, California: Left Coast Press.

VELÍŠEK, J., 1999. Chemie potravin 1. 1st ed. Tábor: OSSIS

YANG, X., MA, Z., WANG, T., PERRY, L., LI, Q., HUAN, X., and YU, J., 2014. Starch grain evidence reveals early pottery function cooking plant foods in North China. Chinese Science Bulletin, 59(32), 4352-4358.

YANG, X., MA, Z., LI, Q., PERRY, L., HUAN, X., WAN, Z., LI, M. and ZHENG, J., 2014. Experiments with lithic tools: Understanding starch residues from crop harvesting. Archaeometry, 56(5), 828-840.

YASUI, E., 2015. Starch and Stone: Preliminary Evidence from Jomon Period Ground Stone in Southwestern Hokkaido. In: The 80 th Annual Meeting of the Society for American Archaeology.

YEUNG, E.C.T., STASOLLA, C., SUMNER, M.J., and HUANG, B.Q., 2015. Plant Microtechniques and Protocols. Springer International Publishing.

TROMP, M., and DUDGEON, J.V., 2015. Differentiating dietary and non-dietary microfossils extracted from human dental calculus: The importance of sweet potato to ancient diet on Rapa Nui. Journal of Archaeological Science, 54, 54-63.

VRANOVÁ, V., DANSO MARFO, T., and REJŠEK, K., 2015. Soil scientific research methods used in archaeology - Promising soil biochemistry: A mini-review. Acta Universitatis Agriculturae et Silviculturae Mendelianae Brunensis, 63(4), 1417-1426.

WANG, J., LIU, L., GEORGESCU, A., LE, V.V., OTA, M.H., TANG, S., and VANDERBILT, M., 2017. Identifying ancient beer brewing through starch analysis: A methodology. Journal of Archaeological Science: Reports, 15, 150-160. 
